\title{
Modeling the Effects of Cloudy Weather on Regional Epidemics of Soybean Rust
}

\author{
A. P. S. Dias, Monsanto Company, St. Louis 63167; and X. Li and X. B. Yang, Iowa State University, Ames 50011
}

\begin{abstract}
Dias, A. P. S., Li, X., and Yang, X. B. 2014. Modeling the effects of cloudy weather on regional epidemics of soybean rust. Plant Dis. 98:811-816.

This study simulated daily development of soybean rust (SBR), caused by Phakopsora pachyrhizi, based on cloud cover conditions. Results from a previous study that determined the relationship between shading and apparent infection rates were applied in this study to simulate SBR progress on a regional scale using a semi-empirical logistic model parameterized according to the observed cloud cover conditions. Depending on local weather data availability, cloudy days were assumed to be either (i) the days with less than $2 \mathrm{~h}$ of full sun or (ii) the days with complete cloud cover as measured by three daily observations. Estimated disease progress and final estimates of epidemic intensity

were verified by 30 reports of seasonal disease progress in 11 regions of Brazil and South Africa from 2002 to 2007. The model predicted final disease severity and the observed final severity fall into a linear relationship with correlation coefficient $r=0.96$ and a slope close to 1 . Severe SBR epidemics occurred when 19.5 or more cloudy days were recorded during the period from initial disease detection to the date of final disease assessment near the end of a growing season in Brazil and South Africa. Mild epidemics were observed with less than eight cloudy days in a season.
\end{abstract}

Soybean rust (SBR), caused by the fungus Phakopsora pach$y$ rhizi, has been reported in most soybean (Glycine max)-growing regions worldwide $(18,32,41)$. In Brazil, SBR was first observed during the 2001-02 season, and outbreaks have been observed in many regions of the country (41). Severe epidemics have also been reported frequently in the mist belt zone of KwaZulu-Natal province in South Africa (30). Although seasonal disease epidemics in these tropical regions have been managed with preventive fungicide sprays, severe yield losses were still observed in regions with favorable weather conditions for disease development $(18,41)$.

Experimental results and field observations from various researchers have demonstrated that $P$. pachyrhizi is sensitive to light $(1,6,13,15,17,20,23,27)$. Germination of urediniospores of $P$. pachyrhizi is inhibited by direct sunlight and germ tubes grow in the opposite direction to a light source $(15,17)$. Sporulation is mostly on the abaxial side of soybean leaves and in the lower canopy, where exposure to direct sunlight is minimal $(2,23,27)$. In field experiments with controlled shading conditions, SBR incidence and severity were greater in the shaded areas than that in plants under full sunlight (6).

In the tropics, severe epidemics of SBR are often observed in regions where prolonged rainfall periods occur $(5,32)$. In addition to providing favorable humidity and temperature conditions, rain clouds may favor SBR epidemics by providing the shading that protects pathogen infection and development from direct sunlight. Similarly, SBR epidemics usually expand to temperate latitudes in Argentina, China, and United States in fall season, when reduced solar radiation intensity occurs $(7,9,19,32)$.

Modeling approaches have employed weather variables to assess potential inoculum survival and epidemic development of SBR in previous studies $(5,16,28,29,38,39)$. Weather factors such as temperatures, rain, and leaf wetness were used mostly as predictors to assess disease development. A few laboratory and field studies have addressed the effects of shading on SBR development as well.

Corresponding authors: X. Li, E-mail: linuslee@iastate.edu; and X. B. Yang, E-mail: xbyang@iastate.edu

Accepted for publication 29 December 2013.

http://dx.doi.org/10.1094/PDIS-03-13-0269-RE

(C) 2014 The American Phytopathological Society
However, sunlight-related weather variables have never been used as a model input at a regional scale.

We hypothesized that the apparent infection rate of SBR is influenced by solar radiation intensity, in addition to other factors mentioned above. Therefore, cloudiness, which affects sunlight intensity, may have the power to explain epidemics of SBR in field conditions. The objectives of this study were to (i) quantify the reduction in SBR apparent infection rates in unshaded environments, (ii) develop a simulation model to estimate seasonal disease progress from apparent infection rates regulated by cloud cover conditions, and (iii) validate our simulations with regional reports of seasonal epidemics in Brazil and South Africa.

\section{Materials and Methods}

Data collection and preliminary analysis. SBR development was simulated in eight regions of Brazil and three regions in South Africa during different growing seasons in 2002 to 2007, totaling 30 distinct rust epidemics, of which the disease monitoring data were collected in several studies (Table 1). Climate data were provided by Instituto Nacional de Meteorologia (Brazil) and the South African Weather Service (South Africa). Weather stations within $100 \mathrm{~km}$ to the disease reports in each soybean-growing region were selected to provide weather data.

Daily observations of rainfall, relative humidity, cloudiness, and temperature were summarized over the main soybean growing season in each region, which usually extends from November to March in both countries. Although most weather data were collected similarly in the two countries, cloudiness was estimated using different approaches. In Brazil, the number of hours of direct sunlight per day was recorded. For this study, days were arbitrarily assumed to be cloudy when less than $2 \mathrm{~h}$ of direct sunlight per day was observed. In South Africa, the fraction of the sky covered by clouds was recorded every day by a trained observer at 00, 12 and $18 \mathrm{~h}$ coordinated universal time. For this study, days were considered cloudy when the sky was more than $7 / 8$ covered by clouds during all three observations.

Seasonal weather variables were compared, including total precipitation (Prcp), number of rain days (Nrd), number of cloudy days (Ncd), average maximum and mean temperatures ( $\mathrm{Tx}$ and $\mathrm{Tm}$, respectively), and the proportion of days with high relative humidity allowing dew formation (Pdd). PROC CORR procedure in SAS (SAS Institute) was used to estimate Pearson's correlation at $P=0.05$. The Ncd required for different epidemic intensities 
was estimated in SAS using the general linear model (PROC GLM) procedure.

Regional epidemics of SBR can be classified empirically as light, moderate, or severe based on average severity rating, yield losses, defoliation, and number of fungicide sprays (Table 2) $(4,10,39)$. Plant pathologists in Brazil and South Africa estimated the intensity of SBR epidemics (Table 1) at the end of the main growing season based on one or more of these criteria. For specific locations in Brazil, more detailed seasonal SBR progress curves were also available $(11,12,24-26,31,35,37)$.

Model parameter estimation. Results from a previous study (6) were used for the parameterization in our model development. In the previous study, the effect of shading on SBR infection and development was determined at the University of Florida in 2006 and 2007. Briefly, potted soybean plants (Mycogen 5N351RR, maturity group 3.5) inoculated with $P$. pachyrhizi were placed for 12 days in shade (provided by shade cloth allowing 20\% solar radiation transmission) or in full sunlight until evaluation for incidence of SBR. Pots were placed on open ground covered by mowed turfgrass. Disease incidence rates were normalized to the largest values in each trial and treatment means were estimated and statistically compared at $P=0.05$. Because a cloudy day was defined as a day with $<2 \mathrm{~h}$ of direct sunlight in Brazil or with cloud coverage on the sky $>7 / 8$ in South Africa, the percentage of direct sunlight reaching the surface on a cloudy day would be close to or much less than the percentage of direct sunlight at $20 \%$ solar radiation transmission rate in the previous experiment. Therefore, we used this parameterization in simulation in this study based on the above approximation.

Disease development over the course of 12 days was treated as a monomolecular process in this previous study. The monomolecular model is appropriate when disease develops exclusively from pri- mary inoculum sources (21). In these trials, there was no time for secondary infections to develop because disease assessment occurred 12 days after inoculation. Therefore, the observed variability in SBR incidence relied on the different monomolecular apparent infection rates $\left(r_{M}\right)$ in the shaded treatment compared with the full sunlight. The monomolecular apparent infection rate is different from the apparent infection rate normally used in a model describing a polycyclic disease progress (e.g., a logistic model). In our study, we used the monomolecular infection rate derived from the previous study as a substitution of the apparent infection rate in the polycyclic disease development for regional SBR development based on field data. The substitution is on a daily basis, such as during disease development simulated by the logistic model in this study; on every day, the model used a new apparent infection rate which was based on a monomolecular infection rate derived according to the cloudiness on that given day.

To estimate the monomolecular apparent infection rates under different light treatments, SBR development in shade and full sunlight was assumed to follow the monomolecular model with all plants initially healthy $\left(Y_{M 0}=0\right)$ and maximum possible disease intensity equal to 1 at time $\mathrm{n}$ (equation 1 )

$$
Y_{M n}=1-\left(1-Y_{M 0}\right) \times \exp \left(-r_{M} \times t\right)
$$

in which $Y_{M n}=$ disease incidence after time $t=n, Y_{M 0}=$ disease incidence at time $t=0$, and $r_{M}=$ monomolecular apparent infection rate. In our case, $n=12$ days and $r_{M}$ represents infection rate under $20 \%$ sunlight.

Under the assumptions of zero initial incidence and uniform primary inoculum, we calculated the rate of change $(\alpha)$ in the monomolecular apparent infection rates $\left(r_{M}\right)$ in full sunlight compared with the shaded conditions. The estimation was based on average final disease incidence observed in both environments within the

Table 1. Soybean-growing regions and seasons with the reported first detection dates and final soybean rust epidemic intensity at various locations in Brazil and South Africa

\begin{tabular}{|c|c|c|c|}
\hline Country, region ${ }^{x}$ & Growing season & First detection dates $^{y}$ & Observed final disease intensity $\mathrm{z}$ \\
\hline \multicolumn{4}{|l|}{ Brazil } \\
\hline \multirow[t]{3}{*}{ Southeastern Mato Grosso } & 2004-05 & 16 December 2004 & Severe \\
\hline & $2005-06$ & 11 December 2005 & Severe \\
\hline & 2006-07 & 6 December 2006 & Moderate \\
\hline \multirow[t]{2}{*}{ Central Mato Grosso } & 2004-05 & 30 December 2004 & Light \\
\hline & $2005-06$ & 28 December 2005 & Light \\
\hline \multirow[t]{4}{*}{ Western Bahia } & $2002-03$ & 7 February 2003 & Severe \\
\hline & 2003-04 & 15 January 2004 & Light \\
\hline & $2005-06$ & 16 January 2006 & Light \\
\hline & 2006-07 & 22 December 2006 & Moderate \\
\hline \multirow[t]{3}{*}{ Northern Rio Grande do Sul } & 2004-05 & 14 February 2005 & Light \\
\hline & 2005-06 & 12 January 2007 & Light \\
\hline & 2006-07 & 11 January 2007 & Light \\
\hline \multirow[t]{4}{*}{ Southeastern Goiás } & $2002-03$ & 15 December 2002 & Severe* \\
\hline & 2003-04 & 9 December 2003 & Severe \\
\hline & $2005-06$ & 30 December 2006 & Moderate \\
\hline & 2006-07 & 27 December 2006 & Severe \\
\hline \multirow[t]{3}{*}{ Northwest São Paulo } & $2002-03$ & 31 January 2003 & Light* \\
\hline & 2003-04 & 18 December 2003 & Severe \\
\hline & $2004-05$ & 12 January 2005 & Light \\
\hline \multirow[t]{2}{*}{ Triangle Minas Gerais } & 2003-04 & 9 December 2004 & Severe \\
\hline & 2004-05 & 15 December 2004 & Moderate \\
\hline \multirow{2}{*}{ Mato Grosso do Sul } & 2004-05 & 28 December 2004 & Light \\
\hline & $2005-06$ & 30 November 2005 & Severe \\
\hline \multicolumn{4}{|l|}{ South Africa } \\
\hline \multirow[t]{3}{*}{ Mist Belt KwaZulu-Natal } & 2003-04 & $\ldots$ & Severe \\
\hline & 2004-05 & $\ldots$ & Severe \\
\hline & $2005-06$ & $\ldots$ & Severe \\
\hline \multirow[t]{3}{*}{ Mpumalanga Province } & 2003-04 & $\ldots$ & Light \\
\hline & 2004-05 & $\ldots$ & Moderate \\
\hline & $2005-06$ & $\ldots$ & Severe \\
\hline Free State & $2005-06$ & $\ldots$ & Light \\
\hline
\end{tabular}

${ }^{\mathrm{x}}$ Cloudy day definitions by the local weather service: less than $2 \mathrm{~h}$ of direct sunlight per day in Brazil locations; average observed cloud coverage on the sky $>7 / 8$ at 00,12, and $18 \mathrm{~h}$ coordinated universal time in South African location. The cloudiness was observed at a local level within a range of $100 \mathrm{~km}$.

${ }^{y}$ First detection dates were reported by Embrapa, Brazil.

${ }^{\mathrm{z}}$ Asterisk (*) indicates that final disease intensity was slightly overestimated by model simulation in these cases. 
time period of 12 days (equations 2 to 4 ). According to the previous study, $r_{M}$ was approximately 0.2 under $20 \%$ sunlight, and approximately 0.05 under full sunlight (6).

$$
\begin{gathered}
Y_{M<S H A D E>}=1-\exp \left(-r_{M} \times t\right) \\
Y_{M<S U N L I G H T>}=1-\exp \left(-\alpha \times r_{M} \times t\right) \\
\alpha=\operatorname{Ln}\left(1-Y_{M<S U N L I G H T>}\right) / \operatorname{Ln}\left(1-Y_{M<S H A D E>}\right)
\end{gathered}
$$

Model development and validation. Development of SBR in natural conditions most likely follows a logistic pattern with maximum disease intensity at 1 (equation 5).

$$
d Y / d t=r_{L n} \times Y_{L n} \times\left(1-Y_{L n}\right)
$$

The logistic model has been used to describe epidemics of polycyclic diseases similar to $\operatorname{SBR}(21,36)$. In this model, increments of disease intensity $(d Y)$ in time $d t$ are regulated by a constant logistic apparent infection rate $\left(r_{L n}\right)$ multiplied by the proportions of both diseased $\left(Y_{L n}\right)$ and healthy plants $\left(1-Y_{L n}\right)$ at time $t=n$. The development of a polycyclic disease relies on secondary inoculum produced on the diseased plants during epidemics.

The logistic apparent infection rate $\left(r_{L n}\right)$ contains information on both infection efficiency and production of secondary inoculum (21,33). Environmental and host characteristics negatively affecting infection and sporulation reduce the apparent infection rate $(14,21,33)$. In this study, we assumed that a logistic model explained disease development, and that other conditions such as temperatures were not limiting the disease development. The apparent infection rate was adjusted daily as a function of cloudiness on a given day so that it was not a constant. Greater apparent infection rates of SBR occur on cloudy days, while the infection rate was reduced by a fraction $\alpha$ (equation 4 ) on a clear day, as calculated from our experimental data. Based on equations 1 through 5, the assumptions led to $r_{L n}=r_{M}$ on a cloudy day and $r_{L n}=\alpha \times r_{M}$ on a clear day.

Unlike monomolecular models, logistic models increase from an established initial disease level. In this study, most of the simulations were set to start at the first detection date reported in the region at a severity level of one lesion per leaf ( 0.4 to $0.8 \%$ by area). This is the minimum detectable level for a trained observer previously reported for SBR (8). One exception was made for the 200203 growing season in Brazil, when SBR was observed for the first time in many regions that lacked trained disease observers. Therefore, the first detection dates in that season did not reflect the minimum detectable levels because the disease was noticed when premature defoliation occurred (40). In these cases, the epidemics of

Table 2. Criteria used to determine disease level: mean severity (MS), estimated yield losses (YL), defoliation (Defol), and average number of required fungicide sprays (Sprays) at different epidemic intensity levels $(4,10,39)$

\begin{tabular}{lcccc}
\hline $\begin{array}{l}\text { Epidemic } \\
\text { intensity }\end{array}$ & MS $(\boldsymbol{\%})$ & YL $(\%)$ & Defol (\%) & Sprays \\
\hline Light & $<20$ & $0-15$ & $<10$ & 0 to 1 \\
Moderate & $20-40$ & $15-30$ & $10-30$ & 1 to 2 \\
Severe & $>40$ & $30-70$ & $30-60$ & $>2$ \\
\hline
\end{tabular}

SBR were considered to have started at least 1 month earlier than reported detections in those regions (40), and disease simulations were given a starting date 1 month before the reported detection dates. In South Africa, the detection dates of SBR were not regularly reported. Thus, model simulations were arbitrarily set to start on December 1 of each year because most soybean fields were usually established at that time and inoculum was locally present (3).

Starting on the detection dates, daily increments of disease severity were calculated from the current ratios of healthy to diseased plant tissue multiplied by the adjusted apparent infection rate according to the daily cloudiness condition for cloudy and nonclouded days (i.e., $r_{L n}=r_{M}$ or $r_{L n}=\alpha \times r_{M}$ ). Daily disease increments were integrated for estimation of disease progress curves and final epidemic intensity (Table 2) at the end of disease development. Modeled final disease intensities were compared with the reported intensity of epidemics observed at each location (Table 1). In several specific cases of disease progress from fungicide trials, the estimated disease progress curves were compared with the disease progress from untreated plots in which more detailed disease information was available $(11,12,24-26,31,35,37)$.

\section{Results}

Disease severity only showed significant $(P=0.01)$ correlation with Ncd and Nrd (Table 3). Among the weather variables, Ncd had a significant $(P=0.05)$ positive correlation with Prcp and Nrd during the epidemics (Table 3$)$. A negative correlation $(r=-0.48)$ was observed between Ncd and average Tm, whereas the correlations between Ncd and Tx and Pdd were not significant at $P=$ 0.05 .

Analyses showed that severe SBR epidemics were reported in regions with more than 19.5 cloudy days between the first disease detection and the final disease assessment date (Table 4). Disease epidemics were much less severe, with minimum yield losses, in regions with less than eight cloudy days (Table 4).

Overall, the cloudiness-based model explained regional development of SBR in both regions, especially in the four cases shown in Figure 1 with more detailed disease progress information. In all, $94 \%$ of the epidemics had final intensity accurately estimated from cloud cover conditions over disease development. However, the model overpredicted the intensity of 2 in 30 epidemic cases. In this study, no final epidemic intensity was underestimated.

The joint correlation between predicted and observed disease severity was estimated to be 0.976 , with a regression line slope of

Table 4. Expected number of cloudy days to cause a certain level of disease severity based on the model simulation from 30 epidemic locations in Brazil and South Africa

\begin{tabular}{lcc}
\hline Epidemic intensity $^{\mathbf{y}}$ & LSM of cloudy days $^{\mathbf{z}}$ & Standard error $^{\text {Light }}$ \\
\hline Moderate & $7.9 \mathrm{a}$ & 1.35 \\
Severe & $13.6 \mathrm{~b}$ & 1.91 \\
\hline
\end{tabular}

${ }^{y}$ Light $=$ disease severity $<20 \%$, Moderate $=$ disease severity of 20 to $40 \%$, and Severe $=$ disease severity $>40 \%$.

${ }^{\text {z }}$ Least-square mean. Estimates followed by different letters differ at $P=$ 0.05 .

Table 3. Estimates of Pearson's correlation among weather variables and disease severity observed at 30 epidemic locations from disease detection to disease assessment date in Brazil and South Africa ${ }^{\mathrm{z}}$

\begin{tabular}{lcccccc}
\hline Variables & Ncd & Nrd & Prcp & Tx & Tm & $\ldots$ \\
\hline Nrd & $0.560^{*}$ & $\ldots$ & $\ldots$ & $\ldots$ & $\ldots$ & $\ldots$ \\
Prcp & $0.396^{*}$ & $0.604^{* *}$ & $\ldots$ & $\ldots$ & $\ldots$ & $\ldots$ \\
Tx & -0.353 & $-0.616^{* *}$ & $-0.596^{* *}$ & $\ldots .535$ & $\ldots$ & $\ldots$ \\
Tm & $-0.487^{*}$ & $-0.567^{*}$ & $-0.572^{* *}$ & -0.378 & -0.278 & $\ldots$ \\
Pdd & 0.090 & $0.664^{*}$ & 0.532 & -0.104 & -0.313 & $\ldots$ \\
Severity & $0.786^{* *}$ & $0.413^{*}$ & 0.195 & -0.022 \\
\hline
\end{tabular}

${ }^{\mathrm{z}} \mathrm{Ncd}=$ number of cloudy days; $\mathrm{Nrd}=$ number of rainy days; Prcp = precipitation $(\mathrm{mm}) ; \mathrm{Tx}=$ average maximum temperature $\left({ }^{\circ} \mathrm{C}\right) ; \mathrm{Tm}=$ average mean temperature $\left({ }^{\circ} \mathrm{C}\right)$; Pdd $=$ proportion of days with dew formation; * and ** indicate significant at $P=0.05$ and 0.01 , respectively. 
1.02 (Fig. 2). The residuals were randomly distributed over time of epidemic development and also over observed disease severity. Nonetheless, the model had a tendency to slightly overpredict disease severity at low disease severity levels.

\section{Discussion}

This model provides a simpler way to describe regional disease development compared with previously developed SBR models $(5,16,38)$. Based on these results, cloud cover was an adequate estimator for modeling apparent infection rates of SBR in Brazil and South Africa, resulting in accurate predictions of the disease's temporal progress and final epidemic intensity. Results demonstrate that Ncd can be used to estimate overall disease develop- ment. The three different Ncd resulting in different disease development levels (Table 4) identified from the analyses were consistent with previous field observations $(32,41)$. In 2 of 30 epidemic cases, our model slightly overpredicted final disease intensity. Both cases were first-time disease outbreaks; therefore, evaluator inexperience may have influenced the ratings of actual disease severity $(8,40)$. Nonetheless, our cloudiness-based model was robust over subjective variations in disease rating because most predictions of SBR severity were consistent with observations from different disease evaluators.

Our cloudiness-based model was successfully extrapolated over time and space. The model structure permitted simulations to be initiated at different times and crop stages (Fig. 1) over a number

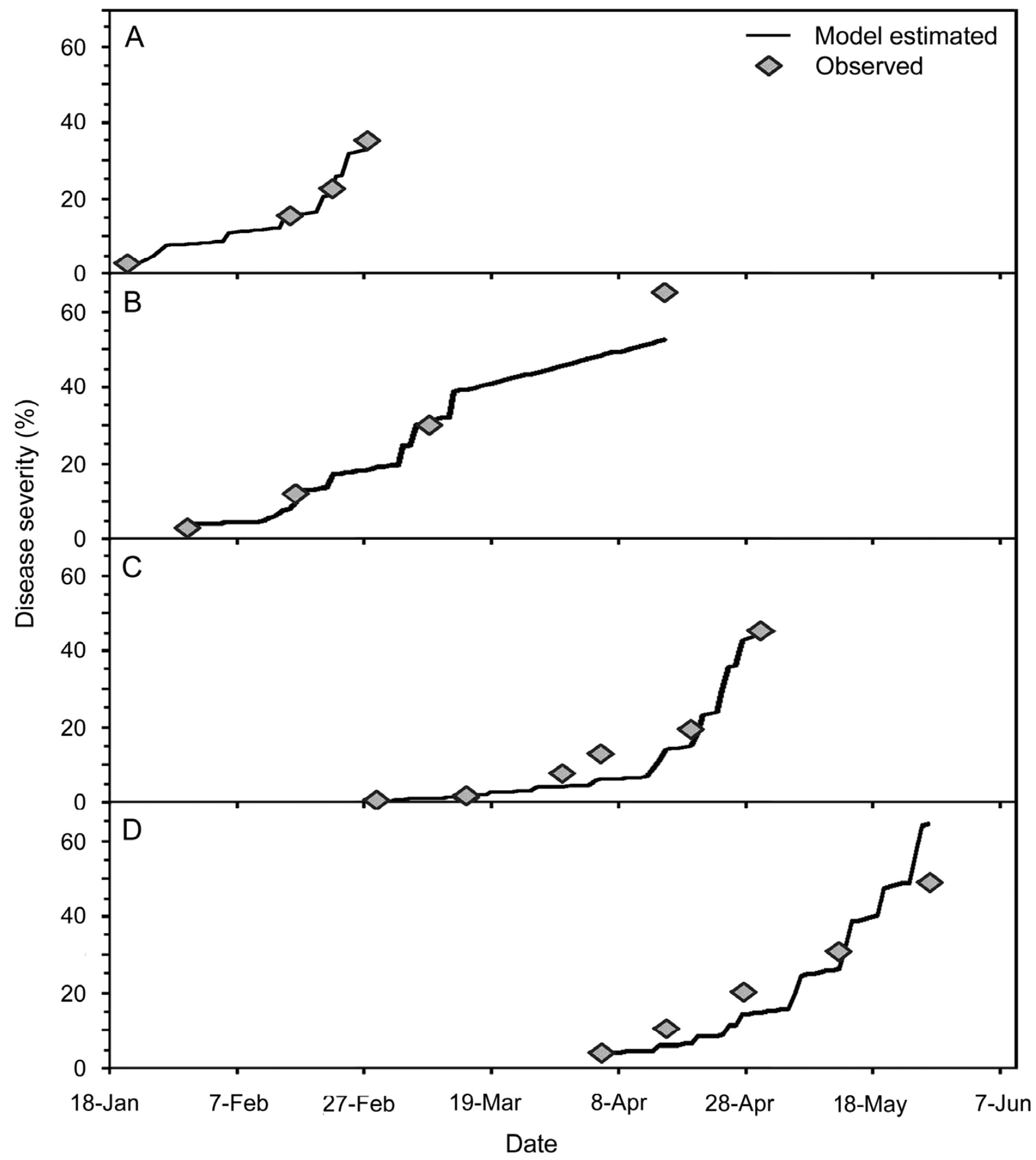

Fig. 1. Estimated soybean rust progress curves using the cloudiness-based model and observed disease severities at four locations in Brazil: A, Uberaba, MG, 2003 (37); B, Barreiras, BA, 2004 (25); C, Mogi Mirim, SP, 2003 (11,12); and D, Itaberá, SP, 2003 (31). 
of regions. However, the model had a strong assumption on disease severity levels at first detection time. Model estimates were based on daily epidemic buildup from initial disease levels. The initial severity values should reflect actual disease values at the starting time so that disease increments are accumulated over accurate initial levels. The success of this cloudiness-based modeling would depend on the presence of sufficient and accurate disease monitoring systems.

Clouds provide shading by blocking direct solar radiation and are also often associated with rainfall in tropical regions. Because both shade and rainfall favor SBR development, as a predictor, cloudiness incorporates both rainfall and shade effects in modeling. In addition to shading and rain, cloud cover may also influence other biologically important weather factors that impact regional SBR development. $P$. pachyrhizi requires specific ranges and time of leaf wetness $(6$ to $8 \mathrm{~h})$ at certain temperatures $\left(22\right.$ to $24^{\circ} \mathrm{C}$ optimal) for infection and development (22). In tropical regions, summer rain events provide moisture and prolonged shading by rain clouds, reducing average temperatures. At most locations in our study, the Ncd and Nrd were positively correlated, while the Ncd and average air temperature were negatively correlated. Thus, lower temperatures may lead to longer leaf wetness duration. Collectively, in these regions, cloudiness used in SBR modeling may serve as an integrated index reflecting multiple effects from other factors, including rainfall, leaf wetness, temperature, and solar radiation, negatively or positively related.

Rainfall, temperature, and leaf wetness have been employed alone or in combination to estimate SBR severity $(5,16,38)$. However, previous models use only one of these factors to assess SBR development regionally. One example is a rainfall-based SBR regression model developed by Del Ponte et al. (5) using data from Brazil. In this study, the variables of accumulative rainfall and rain days (rainfall $>1$ or $5 \mathrm{~mm} /$ day) were observed in a fixed period of 30 days, whereas ours used a simulation model of daily cloudiness as a predictor of the apparent infection rate in disease development. Because rainfall, rain days, and cloudiness in tropical regions are highly correlated, it is not surprising that our cloudiness-based model yielded results similar to those of the rainfall-based model. Both models demonstrate a high ability to describe regional SBR development. However, a simulation model is more flexible than a regression model if daily data are available.

From a modeling perspective, cloud cover is an appropriate and advantageous estimator variable on a regional scale because it exhibits large spatial correlation within regions. Although data collection of a rainfall variable is straightforward, large variations are observed within relatively close locations; therefore, more observations are required to characterize these variables on a regional scale when using a rainfall-based model. In tropical regions of Brazil, similar cloud cover is observed over hundreds of kilometers (34). In this case, only a few observations in a fairly large region are needed to determine regional cloud cover conditions,

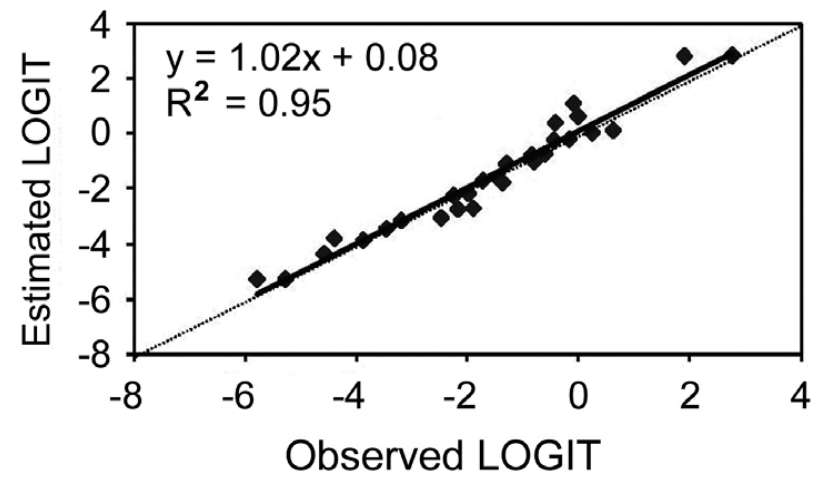

Fig. 2. Predicted disease level versus observed soybean rust severity at seven locations in Brazil, linearized to LOGITS; that is, $\log (P /(1-P)$, in which $P$ is the disease severity in 0 to 1 . The solid line represents the solution for the regression equation and the dotted line represents values of correlation equal to 1 . which simplifies data input of the cloud cover-based simulation model. In many locations of Brazil and South Africa, cloud cover is regularly observed and weather data are typically available to the public through the national weather service. Data accessibility makes this cloudiness-based model simple for growers to use for SBR management in these countries. In the future, the cloudinessbased model and the rainfall model approaches may be combined in order to achieve even more accurate results. The rainfall model could be used to predict general disease risk during early disease development. Once the initial disease level is determined by field surveys, the cloudiness-based simulation model can be incorporated to simulate daily disease progress for more accurate disease forecasts.

Regional risk for severe SBR outbreaks can be estimated in our simulation model from historical patterns of cloud cover. Backward model simulations would determine critical timing for disease onset leading to yield losses based on regional cloud cover patterns during soybean reproductive stages. In general, later SBR onset in a region results in shorter time for disease development. Accurate simulation results would give support for decision making of appropriate management strategies to avoid profit losses on a regional scale.

\section{Literature Cited}

1. Bromfield, K. R. 1984. Soybean Rust. Monograph No 11. American Phytopathological Society, St. Paul, MN.

2. Bromfield, K. R., Melching, J. S., and Kingsolver, C. H. 1980. Virulence and aggressiveness of Phakopsora pachyrhizi isolates causing soybean rust. Phytopathology 70:17-21.

3. Caldwell, P., and Laing, M. 2002. Soybean rust-a new disease on the move. Southern African Society for Plant Pathology Monthly Feature, March 2002. Online publication.

4. De Mori, C., and Costamilan, L. M. 2004. Ferrugem da soja: estimativas de custo de controle, em Passo Fundo, RS. Embrapa Trigo (Documentos, 32), Passo Fundo, RS, Brazil.

5. Del Ponte, E. M., Godoy, C. V., Li, X., and Yang, X. B. 2006. Predicting severity of Asian soybean rust epidemics with empirical rainfall models. Phytopathology 96:797-803.

6. Dias, A. P. S., Li, X., Harmon, P. F., Harmon, C. L., and Yang, X. B. 2011 Effects of shade intensity and duration on Asian soybean rust caused by Phakopsora pachyrhizi. Plant Dis. 95:485-489.

7. Formento, A. N., and Gieco, I. B. 2007. Estadísticas de la detección de roya Asiática de la soja (Phakopsora pachyrhizi) en cultivos durante el ciclo agrícola 2005/06. Instituto Nacional de Tecnología Agropecuaria, INTA Parana, Entre Ríos, Argentina. Online publication.

8. Godoy, C. V., Koga, L. J., and Canteri, M. G. 2006. Diagrammatic scale for assessment of soybean rust severity. Fitopatol. Brasil. 31:63-68.

9. Hartman, G. L., Hines, R. A., Faulkner, C. D., Lynch, T. N., and Pataky, N. 2007. Late season occurrence of soybean rust caused by Phakopsora pachyrhizi on soybean in Illinois. Plant Dis. 91:466.

10. Hartman, G. L., Wang, T. C., and Tschanz, A. T. 1991. Soybean rust development and the quantitative relationship between rust severity and soybean yield. Plant Dis. 75:596-600.

11. Iamauti, M. T., Alvarenga, N. A., and Olson, B. D. 2004. Evaluation of fungicides for control of soybean rust of "BRS-154" soybean, Mogi Mirim, São Paulo, Brazil. Plant Management Network, APS. F\&N Tests 60:FC091. Online publication.

12. Iamauti, M. T., Alvarenga, N. A., and Olson, B. D. 2004. Evaluation of fungicides for control of soybean rust of "IAC-08" soybean, Mogi Mirim, São Paulo, Brazil. Management Network, APS. F\&N Tests 60:FC090. Online publication.

13. Isard, S. A., Dufault, N. S., Miles, M. R., Hartman, G. L., Russo, J. M., De Wolf, E. D., and Morel, W. 2006. The effect of solar irradiance on the mortality of Phakopsora pachyrhizi urediniospores. Plant Dis. 90:941-945.

14. Jeger, M. J. 2004. Analysis of disease progress as a basis for evaluating disease management practices. Annu. Rev. Phytopathol. 42:61-82.

15. Keogh, R. 1974. Phakopsora pachyrhizi Syd.: the causal agent of soybean rust. Aust. Plant Pathol. Soc. Newsl. 3:5.

16. Kim, K. S., Wang, T. C., and Yang, X. B. 2005. Simulation of apparent infection rate to present severity of soybean rust using fuzzy logic system. Phytopathology 95:1122-1131.

17. Koch, E., and Hoppe, H. H. 1987. Effect of light on uredospore germination and germ tube growth of soybean rust (Phakopsora pachyrhizi Syd.). J. Phytopathol. 119:64-74.

18. Levy, C. 2005. Epidemiology and chemical control of soybean rust in Southern Africa. Plant Dis. 89:669-674.

19. Li, X., Engelbrecht, C. J., Mueller, D. S., and Yang, X. B. 2008. First report of soybean rust caused by Phakopsora pachyrhizi in Iowa and its statewide occurrence. Plant Dis. 92:975. 
20. Li, X., Mo, J., Guo, T., and Yang, X. 2010. Effects of light on urediniospore germination, appressorium formation and infection efficiency of Phakopsora pachyrhizi, causal agent of soybean rust. Can. J. Plant Pathol. 32:153161.

21. Madden, L. V., Hughes, G., and van den Bosch, F. 2007. The Study of Plant Disease Epidemics. American Phytopathological Society, St. Paul, MN.

22. Marchetti, M. A., Melching, J. S., and Bromfield, K. R. 1976. The effects of temperature and dew period on germination and infection by urediospores of Phakopsora pachyrhizi. Phytopathology 66:461-463.

23. Marchetti, M. A., Uecker, F. A., and Bromfield, K. R. 1975. Uredial development of Phakopsora pachyrhizi in soybeans. Phytopathology 65:822-823.

24. Martins, M. C., Andrade, N. S., Almeida, N. S., Oliveira, A. S., Lopes, P. V. L., and Silva Filho, J. L. 2004. Avaliação da eficiência de fungicidas para controle da ferrugem asiática da soja em Barreiras, BA. In: Resultados da rede de ensaios para controle químico de doenças na cultura da soja. Safra 2003-2004. C. V. Godoy ed. Embrapa Soja, Londrina, PR, Brazil.

25. Martins, M. C., Andrade, N. S., Almeida, N. S., Tamai, M. A., and Lopes, P. V. L. 2005. Avaliação da eficiência de fungicidas para controle da ferrugem asiática da soja em Barreiras, BA. In: Ensaios em rede para controle de doenças na cultura da soja. Safra 2005-2006, Documentos 266. C. V. Godoy ed. Embrapa Soja, Londrina, PR, Brazil.

26. Martins, M. C., Lopes, P. V. L., Tamai, M. A., Andrade, N. S., Almeida, N. S., and Godoy, C. V. 2006. Eficiência de fungicidas para o controle da ferrugem da soja no oeste da Bahia. Safra 2005-2006. Embrapa Soja, Londrina, PR, Brazil.

27. Melching, J. S., Bromfield, K. R., and Kingsolver, C. H. 1979. Infection, colonization, and uredospore production on Wayne soybean by four cultures of Phakopsora pachyrhizi, the cause of soybean rust. Phytopathology 69:1262-1265.

28. Pivonia, S., and Yang, X. B. 2004. Assessment of the potential year-round establishment of soybean rust throughout the world. Plant Dis. 88:523-529.

29. Pivonia, S., and Yang, X. B. 2005. Assessment of epidemic potential of soybean rust in the United States. Plant Dis. 89:678-682.
30. Pretorius, Z. A., Kloppers, F. J., and Frederick, R. D. 2001. First report of soybean rust in South Africa. Plant Dis. 85:1288.

31. Rosseto, J. A., and Olson, B. D. 2004. Evaluation of fungicides for control of soybean rust of soybean, Itaberá, São Paulo, Brazil, 2004. Plant Management Network, APS. F\&N Tests 60:FC094.

32. Tan, Y. J., Yu, Z. L., and Yang, C. Y. 1996. Soybean Rust. China Agriculture Press, Beijing.

33. Teng, P. S. 1985. A comparison of simulation approaches to epidemic modeling. Annu. Rev. Phytopathol. 23:351-379.

34. Tiba, C. ed. 2000. Atlas solarimétrico do Brasil. Universitária da UFPE, Precife, Brazil.

35. Tofoli, G. R., and Olson, B. D. 2004. Evaluation of fungicides for control of soybean rust of "Esplendor" soybean, Rio Verde, Goiás, Brazil. Online publication.

36. Van der Plank, J. E. 1963. Plant Diseases: Epidemics and Control. Academic Press, New York.

37. Wruck, D. S. M., Paes, J. M. V., and Zito, R. K. 2004. Avaliação da eficiência de fungicidas para controle da ferrugem asiática da soja em Uberaba, MG. In: Resultados da rede de ensaios para controle químico de doenças na cultura da soja. Safra 2003/2004. C. V. Godoy ed. Embrapa Soja, Londrina, PR, Brazil.

38. Yang, X. B., Dowler, W. M., and Tschanz, A. T. 1991. A simulation model for assessing soybean rust epidemics. J. Phytopathol. 133:187-200.

39. Yang, X. B., Royer, M. H., Tschanz, A. T., and Tsai, B. Y. 1990. Analysis and quantification of soybean rust epidemics from seventy-three sequential planting experiments. Phytopathology 80:1421-1427.

40. Yorinori, J. T., and Lazzarotto, J. J. 2004. Situação da ferrugem asiática da soja no Brasil e na América do Sul. Embrapa Soja (Documentos, 236), Londrina, PR, Brazil.

41. Yorinori, J. T., Paiva, W. M., Frederick, R. D., Costamilan, L. M., Bertagnolli, P. F., Hartman, G. E., Godoy, C. V., and Nunes-Junior, J. 2005. Epidemics of soybean rust (Phakopsora pachyrhizi) in Brazil and Paraguay from 2001 to 2003. Plant Dis. 89:675-677. 